\title{
Goods' Assessment in the Crossroad Created from Customs and Tax Practices, Lack of Cooperation and Uniformity of Rules and Laws
}

PhD Candidate Teuta Balliu

\author{
Financial Lecturer at Economic Faculty in "AleksanderXhuvani" University in Elbasan, Albania
}

PhD Marsida Ranxha Ashiku

Doi:10.5901/mjss.2014.v5n13p477

Financial Lecturer at Economic Faculty in "AleksanderXhuvani" University in Elbasan, Albania

\begin{abstract}
The goods' value for customs purposes should be primarily based on what is actually paid for these goods. In the Albanian practice, the intervention on the value of the bill is not something new for neither parts involved in this relationship which can unequivocally be described as complex and dynamic. Customs' administration can use as a way of assessment the method of the discounted value. Said this we understand that it carries the right to verify and compare this value with the cost of declared goods and its purpose is to calculate the tax on profit. As long as the purpose of the customs' and tax's administration is the same we judge that these two institutions of the same structure should not operate separately but coordinate and cooperate together. The coherence between the value for customs purposes and that for tax purposes can serve as a very important controlling tool for state administration in general. In order to function and be utilized properly this controlling means should be firstly decomposed. Then it should be clearly understood the relation between customs valuation and inventory costs. Through this paper, we aim to make an analysis of the methods of evaluation and assessment for customs purposes and costs' valuation of commercial companies for tax purposes. The analysis highlights their similarities and differences.
\end{abstract}

\section{Introduction}

Taxes affect directly the level of demand and employment. Fees and taxes also affect the level of savings and the investment type (Gayer \& Rosen, 2010, p. 37). They influence the distribution way of resources which often lead to inefficiency. The level and structure of taxes determine the level of disposable incomes, and the direction in which they go or the net incomes are distributed (Meiszkowski, 1996, p. 1104). The pre-tax incomes realized by an economic operator among other things, also depend on the value of imported goods. The tax on income paid by commercial importing companies mostly depends on known costs. If the customs value for raw materials, semi-finished or finished products is low than the cost of sold goods will be low too. This way the amount of taxes paid by the derived incomes will be higher. Taxpayers, which in our case are economic operators, prefer low customs value and high costs for the sold goods as both these components reduce the base and the paid tax thus realizing their main economic purpose, which is a higher profit. The same as in many other issues the goal of tax and customs administration as well as in this case goes on another direction to that of the economic operators (Nations, 2013, p. 41). Their main purpose is to collect as much revenues as possible. As long as we agree that there is a relationship between legal rules and norms of tax and customs assessment we can say that the coherence between the value for customs purpose and that for tax purpose can serve as a very important tool for the control of state administration in general. Initially, this article will discuss goods' assessment for customs purposes and further proceed with the goods' assessment, inventory and expenses for tax purpose. Under this approach we aim to highlight their differences and their similarities and concluding it with suggestions and recommendations.

\section{Goods' Assessment for Customs Purpose}

Customs' valuation procedure must ensure a fair, impartial and uniform system excluding the use of fictitious, arbitrary customs values and things not found in law. It should be based on clear, simple and right criteria in accordance with commercial practices. All the WTO member countries, as well as Albania which is member since September 2000, are obliged to implement the Agreement on Implementation of Article VII in the "General Agreement on Tariffs and Trade" (GATT) of 1994. Before we have a look at the methods of assessment for imported goods we think it is important to specify what the statistical value of imported goods involves or simply said the goods' value. 


\subsection{Goods' value}

In order to calculate goods' value we add some other elements to the paid price which should not be included in the actual paid or payable price. Elements which have been in charge of the buyer but are not included in actual paid price of the bill, are as follows:

- Commission and mediation expenses excluding purchasing commissions

- Goods' holder costs

- Packing cost which includes both the materials and the work that is done

Furthermore in order to determine the custom's value we also add the right apportioned value of goods and services that we are going to list below to the actual paid or payable price. Of course we should bare in mind that this add-on will be made in cases where and to the extent that it is not included in the bill's price and when they are carried to the place of entry into the customs territory of our country. The above elements are:

- Materials consumed in the production of imported goods and embedded in them.

- Matrixes, molds etc used for the production of imported goods

- The engineering, designing work etc, made outside our country and necessary for the production of the imported goods.

- Payment on the right of intellectual property and the license right

- The value of any part of the proceeds of any subsequent resale, disposal or subsequent use goes to the seller of the goods.

- The costs of transportation, insurances, and loading to the place of entry in RA

Besides the elements that should be added we should also mention elements which are not included in the custom's value. Not included elements involve:

- Payment on the right of reproduction in our country

- Payment on the right of distribution or resel in our country

- Payment ofter importing which are related to fitting, maintenance, technical assistance, taxes and transportation costs.

\subsection{Valuation methods}

Once we have shed light on the goods' value, let's see what the methods of custom's valuation are. All goods imported into the territory of the Republic of Albania should be evaluated in accordance with one of the six methods provide in the Custom's Code of Albanian Republic.

I. Transaction value

This evaluation method is provided in the Custom's Code (CC) Article 35, paragraph 2, letter a. The transaction value is the good's actual paid or payable price when sold for export to the country of importation adjusted in accordance with regulations prescribed by the legislation in force (Frederik Zhara, Shamet Shabani, 2005, p. 111). The actual paid or payable price is the total payment made or to be made by the byer to the seller or in favor of the seller for the imported goods.

II. The transaction value of identical goods (CC Article 35 paragraph 2, letter b).

According to this method imported goods can be assessed with reference to the transaction value of identical goods sold for export in the Albanian Republic or exported at about the same time as the goods which are being assessed. Identical goods are goods produced in the same place, which are the same in every aspect including physical characteristics, quality and reputation.

III. The transaction value of similar goods (CC Article 35, paragraph 2, letter b).

The custom's valuation methods have hierarchical nature. Said this we understand that if none of the first two methods is not applied for different reasons we can move on the third method which assesses imported goods under the transaction value of similar goods. According to this assessment method the base of the assessment is the transaction value of similar goods sold for export to the Albanian Republic and exported at about the same time as the goods which are being assessed (Frederik Zhara, Shamet Shabani, 2005, p. 111). Similar goods are goods produced in the same place, which are not similar in every aspect but have similar characteristics and component materials and perform the same functions. Quality, reputation and trade marks are determining factors for similar goods.

IV. Discounted value (CC Article 35, paragraph 2, letter c). 
According to this method the assessment is done with the value based on the unit price of similar or identical goods. These similiar or identical goods must be imported and sold within the country in the largest amount to people not related to the sellers. Further more the sales are discounted certain expenses inside the country. When calculating the custom's value using the discounted value method we should be careful and take into consideration the following:

- Selection of the right price

- Time of sale and conditions under which the goods are sold

- The largest aggregate amount

Besides selecting the right price we should pay particular attention to elements such as sale time and the conditions under which the sale is/was done. There are two main conditions. The first condition is that all the goods we refer to must or should be imported on or around the date of import. The second condition relates again to the fact that these goods must be imported within 90 days from the date of the imported goods that are being assessed.

Following the above considerations, the next step is the application of certain discounts which are listed below:

- Commissions or profits for general expenses

- Transport and insurances

- Customs' duties and other taxes

- Other costs

- Commission that is usually paid or agreed to be paid, additions which are usually made for profit and general expenses (including direct and indirect costs which are used to advert the goods in question) connected with the sales in the Albanian Republic, the goods of the same category and kind of imported goods.

- Import Custom Duties and other payable fees which should be paid in the Albanian Republic due to importation and sale.

- Common expenses related to transport and freight insurance as well as the additional costs associated with these two categories.

V. Calculated value (CC Article 35, paragraph 2, letter d).

Through this method we will see the production of imported goods and calculate the goods' costs. It consists in determining the materials and the production costs, which in this care are:

- All direct labor costs

- All installation costs

- Machines used in manufacturing

- Indirect costs such as factory maintenance, and supervision as well as paying overtime working.

- Material costs such as containers, packaging, and services costs.

Besides determing the materials and the manufacturing costs we can not leave outside of the focus the benefits and costs that are equal to that reflected in the sales of the same class or kind goods as well as the benefits and general expeses as a whole. There are other general expenses, such as salaries, rent, marketing, legal fees, and telephone, depreciation, as well as office equipments, services, capital equipment and employee benefits.

VI. Methods of available data (CC Article 39)

When the customs value of imported goods can not be determined under section 34 or 35 , it is then determined on the basis of available data. In the customs practice this is known as reference value. Information sources are based on the following:

- Prices of International Markets taken from Thomson-Reuters Agency, PLATTS, London Metal Exchange, Profercy, ICIS, etj.

- International bulletins such as STELL WEEK, METAL BULETIN, TEC DOC, etj.

- International publications such as QuattroRuote, Tuttu Transporti , Zacke, etj.

- Confirmed invoices

- Published prices by Eurostat OBT, UN Comtrade.

- Statistical data. 


\subsection{Goods' e valuation for tax purposes}

Every state has its rules, laws, norms and fiscal packages and indisputably politics and business are essential for their success. There is no "one size fits all" — but there are lessons that can help guide countries as they move forward in the reform process. (OECD, 2011, p. 18). In Albania all financial statements are constructed under Law No 766 'Accountings' and other rules and guidelines of the Ministry of Finances. The statement of expenses and incomes shows the difference between total revenues and total expenses (The Assembly, Instruction No. 5 date 31.06.2006 "For income tax, changed", 2019, p. 19). The financial statements are formulated in such a way as to reflect the needs of all users (The assembly, Law No. 8438 date 28.12.1998 "On Income Tax, changed" 2014, p.6). The main users of financial statements can be the owners and the managers, the lenders and the other creditors, the government for micro and macro planning, tax authorities for tax assessments and SME agencies in order to assess the required support of micro units (Accounting, $2009, p$ 7). The tax base on which the tax rate of the profits is applied, is defined on the basis of the financial statements and their attached annexes. Taxes paid in customs on imported goods are part of the expenses of a company. However, before we talk about expenses let's mention the reasons of changing profits before tax. Possible changes in profit before tax, so in the gross one may come from one or several factors together, such as: (Xhafa, 2005, p. 129):

- Increase or decrease in the sale's volume

- Increase or decrease in the price of unit sale

- Increase or decrease in the costs of unit sale

Let's treat the third factor, which in fact is the focus of this paper. Expenses are outflows, because they are reductions in the economic benefits during the reporting period, which result in reduction of assets and increase of liabilities and they increase the capital of the reporting entity, excluding those related to contributions from the capital participants (Accounting, 2009, p 5). Costs are devided into two main groups, in the costs of sold goods and general expenses that every business creates but which are not associated with the manufacture of products. We can distinguish two separate assessment categories for the entry and exit inventories made in the stores. Inventories are initially measured with costs (IKM, 2006, p. 72). The cost of inventory balances must include all the costs of acquisition, transformation (processing) and others until the product is brought to the place and situation in which it should be. The calculation of acquisition costs is done by substracting from the purchasing price the discounts obtained on the purchasing price (rebates margins) and adding the other purchasing costs in order to bring them to the present situation and than are further devided in internal and external. External expenses include the following elements:

- Mediation commission costs associated with purchasing.

- Transit costs

- Transport and insurance costs conducted by third parties

- Customs costs

- Costs of non refundable taxes

While the internal cost includes stevedoring and transport by own means it does not include elements such as:

- Costs of supplying function such as those for selecting bids, tenders, contracts' planning, making orders, admission control etc

- Costs after entry

- Financial costs such as interest for trade loans taken for purchases, etc

However, it belongs to financial units to decide whether to include certain expenses in the production costs. In any case it should be guided on one side by the need of setting the most realistic margin provided by each product, which emerges as a difference between the selling price and the costs of production and on the other hand by adhering to the care principles which require not allowing costs or risks crossing without a safe covering source from one period to the others. In order to make a more accurate assassement of the elements entering the assets in stock form we should first make the distinction between identifiable elements and the dissolved ones, ie that after entry can not be identified one by one. Let's take a look on the assessment of identifiable elements. Initially the reporting unit should record the inventory when in control, when expecting economic benefits and then its cost can be estimated reliably. Specific identification of costs means that specific costs are defined to elements belonging to identifiable inventory balances. This method can be used for identifiable elements whether purchased or produced by you. It can be used when there is a large amount of dissolved elements. Regarding the assessment of dissolved elements we can say that accounting standarts predict that this stock category can use the methods with reference to law and an alternativemethod as well. FIFO (first entry, first exit) and that of weighted average are the reference methods accepted by the law. According to reference methods the materials that enter first in stoch should be the first to come and so on. This way the stock that remains at the end of the 
period contains the latest entries in the stock. According to the other method that of the weighted average, the cost of every item is determined from the weighted elements such as the cost of analog items at the beginning and then the cost of purchased/manufactured items during the period. This average can be calculated periodically or for every new movement in the stock according to the specific situation of each economic unit. An accepted alternative method is that of LIFO (last entry first exit). This method assumes that stock elements which are purchased or produced last are the first to exit. Thus, consequently balances at the end of certain periods consist of elements which have been put in stock a long time ago.

\section{Conclusions and Recommendations}

International business relations, regardless of the sector or the country where transactions are executed face different problems related to the assessment of goods. These problems arise because the goods' assessment is something which is handled by the customs administration as well as the tax one. The problems increase even more as long as the rules according to which the goods' asseement is made change. Making the assessment according to same basis, rules and practices would be in the interest of all parties participating in the goods' assessment. Customs and tax administration seem to to share the same rules and concepts but do not interact in carrying out controls which will unquestionably bring what is more important, thus the same practices. After treating this topic we come in the conclusion that the problem of good's assessment arises for two main reasons:

First, even though customs and tax administration are part of the same department that of Ministry of Finance, they use differen bases for the same reason which is that of raising public revenues. Tax administration raises more revenues from the tax by increasing sales prices and the customs administration on the other hand increases the value of the bill in order to achieve more public revenues. This is all translates into more costs for the companies. Secondly, both these bodies apply different rules for the same issue such as the good's assessment.

There are certain terms which condition the preparing of a new package of legal acts in the fiscal field. Among them we find the globalization in the economic field, volume growth of import and export, the increasing tendency for getting free from barriers, customs tariffs and new challenges that business is facing. Further more today we are looking for improvements and unification with the legislation of the European Union. In this context, finding adequate legal provisions, its content meaning and especially the simultaneous application of several customs and tax provisions is a primary and responsible task for the institutions that operate in the fiscal field. Cooperation between the two above mentioned institutions is seen as neccessity. Customs and tax administrations should increasingly cross and exchange informations between each other. National and international transactions require harmonized tax and custom assessment, clear and easy rules and norms in order to be understood by each party participating in the transaction. They also require decrease in the financial impact related to the goods' assessment. What we require in this time and complicated market is that companies should not be perceived as source of incomes but as partners. All parties need solutions and it is obvious that it requires inclusiveness, harmonization and national or international standardization.

\section{References}

Department of Economic \& Social Affairs, U. N. (2013). Practical Manual on Transfer Pricing for Developing Countries. New York: United Nations.

Frederik Zhara, Shamet Shabani. (2005). Legjislacioni Doganor. Tirane: ADA.

Gayer \& Rosen. (2010). Public Finance. Tirane: UET Press.

IKM. (2006). Standartet Kombetare te Kontabilitetit. Tirane: IASB.

Kontabilitetit, K. K. (2009). Standartet Kombetare te Kontabilitetit. Tirane: Keshilli Kombetar i Kontabilitetit.

Kuvendi, R. (2014). Ligji nr 8438 dt 28.12.1998 "Per tatimin mbi te ardhurat, i ndryshuar". Tirane: Drejtoria e Pergjithshme e Tatimeve.

Kuvendi, R. (2013). Udhezimi nr 5 dt 31.01.2006 "Pet tatimin mbi te ardhurat, i ndryshuar". Tirane: Drejtoria e Pergjithshme e Tatimeve.

Meiszkowski, P. (1996). Tax incidents theory: The effects of taxes on the distribution of income. Journal of Economic Literature , 11031124.

Nations, U. (2013). Practical manual on Transfer Pricing. New York: United Nations.

OECD. (2011). Supporting the Development of more Effective Tax Systems. Paris: OECD.

Xhafa, H. (2005). Analiza e Parqyrave Financiare. Tirane: PEGI. 